\title{
BMJ Global Health Enhancing global health engagement in 21st century China
}

\author{
Jian Wu, ${ }^{1}$ Soumitra S Bhuyan (iD , ${ }^{2}$ Xiaoli Fu ${ }^{1}$
}

To cite: Wu J, Bhuyan SS, Fu X. Enhancing global health engagement in 21 st century China. BMJ Global Health 2020;5:e002194. doi:10.1136/ bmjgh-2019-002194

Handling editor Seye Abimbola

Received 29 November 2019 Revised 21 February 2020 Accepted 28 February 2020

Check for updates

(c) Author(s) (or their employer(s)) 2020. Re-use permitted under CC BY-NC. No commercial re-use. See rights and permissions. Published by BMJ.

${ }^{1}$ College of Public Health, Zhengzhou University,

Zhengzhou, China

${ }^{2}$ Edward J. Bloustein School of Planning and Public Policy, Rutgers University, New Brunswick, New Jersey, USA

Correspondence to

Professor Xiaoli Fu;

xlfu66@126.com

\section{INTRODUCTION}

Since the opening up and reforms that began 40 years ago, China's economy and society have developed rapidly. It is estimated that between 1978 and 2017, China's Gross Domestic Product (GDP) increased on an average of $9.5 \%$ annually, and per-capita GDP growth was about 22.8-fold. ${ }^{1}$ During the same period, more than 700 million Chinese people were lifted out of poverty. ${ }^{2}$ Consequently, China has become a much healthier nation. The average life expectancy in China rose from 65.2 years in 1978 to 76 years in $2017 .{ }^{3}$ China did remarkably well in meeting the Millennium Development Goals of reducing infant mortality and improving maternal health. ${ }^{4}$ For example, under-five mortality dropped from $54 \cdot 1$ death per 1000 live births in 1990 to 12.5 per 1000 live births in 2015. Similarly, the maternal mortality ratio declined from 111.0 deaths per 100000 live births to 21.8 per 100000 live births during the same time. ${ }^{45}$

China has also established the most extensive universal health insurance network in the world, covering more than $95 \%$ of the population since $2011 .^{6-8}$ Less than $50 \%$ of the Chinese population had any health insurance in 2005. About $97 \%$ of the rural population (approximately $45 \%$ of the Chinese population) have access to health insurance under the Rural Cooperative Medical Scheme. ${ }^{6}$ Similarly, since 2008, the vaccination rate reached more than $90 \%$ coverage rate under the National Immunization Program. ${ }^{9}{ }^{10}$ As part of China's ongoing effort for global engagement, a new China International Development Cooperation Agency (CIDCA) was launched in $2018^{11}$; a platform for China to better participate in global health governance, as its status changed from being a recipient country to a donor country. ${ }^{11} 12$ In this editorial, we highlight China's contribution to global health in the last four decades and the opportunities ahead as China establishes itself a major player in global health.

\section{CHINA'S BELT AND ROAD INITIATIVE}

The Belt and Road Initiative (BRI) emerged as one of the most significant foreign policy agenda for China in the last decade. ${ }^{13} 14$ The BRI emphasises infrastructure development but also promotes policy dialogue, infrastructure connectivity, unimpeded trade, financial support and people-to-people exchange between counties in Asia, Africa and Europe. ${ }^{13}$ So far, over 70 countries containing about $65 \%$ of the world's population and around one-third of the GDPs have signed up for this new initiative. ${ }^{15}$ This new initiative, which promotes the trading of goods and the movement of individuals among countries across different continents, will also elevate the risks of diseases. ${ }^{1316}$

Notably, as a part of the BRI, the Health Silk Road was created to promote cooperation in disease prevention, health promotion, policy development, capacity building, training of healthcare workforce and exchange, and to assist member countries during disasters and emergencies. ${ }^{17} \mathrm{~A}$ survey was conducted among healthcare experts of 29 countries covered under the BRI initiative to understand the intentions, needs, advantages and barriers in participating in the BRI Health Cooperation. ${ }^{18}$ Based on prior evidence, we have identified critical areas for further collaboration. We also underscore the importance of establishing long-term partnerships and platforms to facilitate communication and mitigate cultural differences. ${ }^{18}$

\section{CHINA'S GLOBAL HEALTH AID}

Developmental assistance for health (DAH), including humanitarian aid, is a significant issue in contemporary international politics. ${ }^{13} 14$ Throughout the 20th century, China has actively participated in numerous global health activities. China had provided nearly $¥ 400$ billion of development assistance to 166 countries and international organisations and dispatched more than 600000 aid 
workers. ${ }^{19}$ A recent example is China's role in containing the 2013-2016 outbreak of Ebola. ${ }^{13}{ }^{20}$ China has also offered emergency aid to several West African countries with weak public health infrastructure and human resources as well as offer support to WHO and United Nations' public health governance system. ${ }^{20}{ }^{21}$ As shown in a recent BMJ Global Health paper, DAH from China saw substantial increase in total funding between 2007 and 2017. ${ }^{22}$ Although China's contribution for DAH is among top 10 for donor countries, its contribution relative to the population size and the GDP is still far behind the traditional countries participated in global developmental assistance. $^{22}$

China's foreign aid for global health is often provided in five general sectors, medical teams, hospital development, drug and equipment donations, healthcare employee training and infectious disease control such as malaria, with the most significant component of aid being aimed at medical teams and facilities. ${ }^{14}{ }^{17}$ In a keynote speech delivered at the opening ceremony of the 2018 Beijing Summit of the Forum on China-Africa Cooperation, the Chinese President Xi Jinping announced its decision to revitalise 50 medical and health aid programs in Africa, including the African Center for Disease Control and Prevention and China-Africa Friendship Hospitals. ${ }^{23}$

Although China's foreign aid contribution is relatively low as compared with other major donor countries, China has an extensive history of successfully sharing technical expertise with many other countries, especially small developing countries for infectious disease management. ${ }^{1724}$ In the last few decades, many countries have adopted different Chinese models for infection control and the elimination of certain diseases like lymphatic filariasis, malaria and tuberculosis, among others. ${ }^{17}$ In 2016, China and WHO signed the China-WHO National Cooperation Strategy (2016-2020), with a focus on the development of health policies, planning, technology adoption and human resources management. ${ }^{25}$ In 2017 , China signed a memorandum of understanding with WHO on 'Implementation Plan for the One Belt, One Road Health Sector Cooperation', to work together on issues such as medical emergencies, infectious disease prevention and traditional medicine in countries along the BRI. ${ }^{26}$ One major challenge in estimating China's health aids lies in limited data transparency. ${ }^{27}$

\section{CHINA'S GLOBAL HEALTH INFLUENCE IN THE 21ST CENTURY}

China has done remarkably well in improving the health of the Chinese people in the last few decades. But major challenges lie ahead of China in the quest to establish itself as a major global health power. To improve its global health engagement, China needs to:

I. Develop a clear global health agenda: 21st Century globalisation is inextricably linked to health. China must determine the position of global health in its national development strategy with unprecedented priority and clarity. China already has a clear overall national development strategy, the 'Chinese Dream', and cooperation and exchange of expertise under the 'Health Silk Road' is an encouraging start towards a robust global engagement. However, the commitment can be only sustainable with clearly defined priorities in both domestic and foreign policies.

II. Establish itself as a credible global health actor: the CIDCA is only the first step towards this goal. China needs to incorporate into its global health agenda all relevant government departments, state-owned and private enterprises, medical institutions, public health research centres, healthcare and policy think tanks, private foundations, charity organisations and religious entities. In addition, China needs to ensure increased transparency of its health aid data as this will improve tracking of these funds, increase collaboration between China and other major donors to address high priority areas, and promote more efficient allocation of these resources. ${ }^{27}$

III. Continue its focus on environmental issues: China is playing a proactive role in environmental issues like climate change. China is the highest producer of wind and solar energy in the world. ${ }^{28}$ Although China's rate of emission per GDP has decreased, China is still the largest carbon dioxide $\left(\mathrm{CO}_{2}\right)$ emitter in the world, and the total emission is increasing. ${ }^{29}$ Given the centrality of climate change to global health, China should continue investing in renewable energy sources to mitigate the health risks from pollutions and reduce global carbon emission.

IV. Increase its focus on food safety standards: food safety is a significant public health concern. ${ }^{30}$ Food safety suppressed all other safety concerns, including public security, traffic safety, medical safety, and so on, in China. ${ }^{31}$ In the last decades, there are major incidents reported related to food safety issues in China. ${ }^{32}$ As China is exporting many food products globally, food safety is also becoming a major global health concern. Although the Chinese government has enacted many regulations in recent years to strengthen food safety in China, including establishing the China Food and Drug Administration as the central authority in 2013, the challenge remains in the implementation of these laws due to the fragmented nature of China's food industry. ${ }^{32}$

$\mathrm{V}$. Increase its cooperation with international nongovernmental organizations: this would be necessary for promoting health and well-being in many lowincome countries. Prior evidence suggests that public-private partnership models are useful change agents in global health. ${ }^{33}$ China should continue to engage in more public-private partnerships, both within China and globally, through multilateral initiatives (eg, the United Nations agencies), and through dialogues and financial assistance to encourage the private sector innovations and support for the public sector and global institutions. 
VI. Support low-income countries connected by BRI to develop electronic health infrastructure: this would enhance their health systems and sharing health information data to understand the spread and patterns of diseases better, and also help those countries better respond to their health challenges. So far, the majority of China's global health outreach has focused on infrastructure development. ${ }^{12}$ But there is a need to focus on 'electronic infrastructure' in addition to providing assistance for physical infrastructures such as hospitals and research centres.

VII. Train and retain foreign scholars in China: in the last few years, an increasing number of students and scholars from many low-income and middle-income countries have received academic scholarships from the Chinese government to attend universities in various disciplines. ${ }^{34}$ It is essential to retain some of these global talents in China to enhance mutual understanding of political, social and cultural issues, and to influence China's global health policies and operations.

VIII.Develop global health training programs for students in China: this is necessary to encourage more Chinese students and scholars to visit other low-income and middle-income countries and study their health systems and policies. Like many schools of public health in high-income countries, Chinese universities should offer global health courses, ${ }^{35}$ English language degree programmes in global health $(\mathrm{eg}$, Master of Global Health), targeting both Chinese and foreign students. As a model of south-south learning and exchange, the curriculum should be developed, drawing on lessons from China's experience and success.

\section{CONCLUSION}

Health is a vital pillar of a knowledge-based economy. As an emerging and increasingly dominant economy, China is expected to, and will likely take on more responsibilities and gain more influence in global health governance. But to realise its potential and enhance its influence, China will need to develop a clear global health agenda, establish itself as a credible global health actor, continue its focus on environmental issues, increase its focus on food safety standards, increase its cooperation with international organisations and multilateral initiatives, support health infrastructure development in lowincome countries with a focus on electronic health infrastructure, train and retain foreign scholars in China, and develop global health training programmes for students in China. Even with ongoing challenges, including addressing its domestic health issues, China has a vital role to play in making the world a healthier place.

Contributors WJ wrote the first draft. SSB and FXL commented on the first draft and revised the manuscript.

Funding This study was funded by National Key R\&D Program of China (2018YFC0114501).
Competing interests None declared.

Patient consent for publication Not required.

Provenance and peer review Not commissioned; externally peer reviewed.

Data availability statement All the data provided.

Open access This is an open access article distributed in accordance with the Creative Commons Attribution Non Commercial (CC BY-NC 4.0) license, which permits others to distribute, remix, adapt, build upon this work non-commercially, and license their derivative works on different terms, provided the original work is properly cited, appropriate credit is given, any changes made indicated, and the use is non-commercial. See: http://creativecommons.org/licenses/by-nc/4.0/.

\section{ORCID iD}

Soumitra S Bhuyan http://orcid.org/0000-0002-7247-4438

\section{REFERENCES}

1 China's economic development in 40 years. Available: http://www. chinadaily.com.cn/business/chinaecoachievement40years/index. html [Accessed 12 Nov 2019].

2 Terry S, Luo C, Li S. The long-term evolution of income inequality and poverty in China. World Institute for Development Economic Research (UNU-WIDER), 2018.

3 Life expectancy at birth, total (years)-China. Available: https://data. worldbank.org/indicator/SP.DYN.LE00.IN? locations=CN [Accessed 25 Nov 2019].

4 Guo Y, Huang Y. Realising equity in maternal health: China's successes and challenges. Lancet 2019;393:202-4.

5 Report on China's implementation of the Millennium Development Goals (2000-2015). Available: https://www.fmprc.goåv.cn/mfa_eng/ zxxx_662805/W020150730508595306242.pdf [Accessed 12 Nov 2019].

$6 \mathrm{Yu} \mathrm{H}$. Universal health insurance coverage for 1.3 billion people: what accounts for China's success? Health Policy 2015;119:1145-52.

7 Fang $\mathrm{H}$. The Chinese health care system. Available: https:// international.commonwealthfund.org/countries/china/ [Accessed 12 Nov 2019].

8 Jiang C, Ma J. Analyzing the role of overall basic medical insurance in the process of universal health coverage. Chinese Health Service Management 2015;2:108-10.

9 WHO. China: WHO and UNICEF estimates of immunization coverage: 2018 revision. Available: https://www.who.int/ immunization/monitoring_surveillance/data/chn.pdf [Accessed 12 Nov 2019].

10 China maintains high vaccination rate: official. Available: http://www. xinhuanet.com/english/2019-02/25/c_137849510.htm

11 China international development cooperation agency. Available: http://en.cidca.gov.cn/ [Accessed 14 Nov 2019].

12 Tuangratananon T, Tang K, Suphanchaimat R, et al. China: leapfrogging to become a leader in global health? J Glob Health 2019;9:010312.

13 Tang K, Li Z, Li W, et al. China's silk road and global health. Lancet 2017;390:2595-601.

14 Liu P, Guo Y, Qian X, et al. China's distinctive engagement in global health. Lancet 2014;384:793-804.

15 Belt and road initiative (BRI) European bank for reconstruction and development. Available: https://www.ebrd.com/what-we-do/beltand-road/overview.html [Accessed 14 Nov 2019].

16 Lloyd 's City Risk Index Asia Pacific. Available: https://cityriskindex. lloyds.com/wp-content/uploads/2018/06/Lloyds_CRI2018_APAC. pdf [Accessed 14 Nov 2019].

17 Chen J, Bergquist R, Zhou X-N, et al. Combating infectious disease epidemics through China's belt and road initiative. PLoS Negl Trop Dis 2019;13:e0007107.

18 Wang Y, Liang X, Liu Y, et al. The intentions, needs, advantages and barriers: a survey of twenty-nine countries participating in the "Belt and Road Initiative" health cooperation. Glob Health Res Policy 2019;4:4.

19 China: a source of certainty and stability in a changing world. Available: https://www.fmprc.gov.cn/mfa_eng/wjbxw/t1709807.shtml [Accessed 16 Nov 2019].

20 Huang Y. China's response to the 2014 Ebola outbreak in West Africa. Glob Chall 2017;1:1600001.

$21 \mathrm{WHO}$ and China sign new agreement on Ebola response. Available: https://www.who.int/china/news/detail/31-08-2018-who-and-chinasign-new-agreement-on-ebola-response [Accessed 14 Nov 2019]. 
22 Micah AE, Zhao Y, Chen CS, et al. Tracking development assistance for health from China, 2007-2017. BMJ Glob Health 2019;4:e001513.

23 Xi says China to implement eight major initiatives with African countries. Available: http://www.xinhuanet.com/english/2018-09/03/ c_137441563.htm [Accessed 14 Nov 2019].

24 Hipgrave D. Communicable disease control in China: from MAO to now. J Glob Health 2011;1:224.

25 China-WHO country cooperation strategy 2016-2020. Available: http://www.wpro.who.int/china/160321_ccs_eng.pdf

26 China and WHO adopt transformative approach: linking health and economic development with new agreement on one belt one road initiative, 2017. Available: http://www.wpro.who.int/china/ mediacentre/releases/2017/20170119-mr-president-xi-visit-to-WHOHQ/en/

27 McDade KK, Mao W. Making sense of estimates of health aid from China. BMJ Glob Health 2020;5:e002261.

28 China storms past US and Japan to take lead in wind and solar power. Available: https://asia.nikkei.com/Business/Energy/Chinastorms-past-US-and-Japan-to-take-lead-in-wind-and-solar-power [Accessed 15 Feb 2019].
29 China's role 'critical' if world is to meet climate change targets. Available: https://www.scmp.com/news/china/society/article/ 3047916/chinas-role-critical-if-world-meet-climate-change-targets [Accessed 15 Feb 2019].

30 Lam H-M, Remais J, Fung M-C, et al. Food supply and food safety issues in China. The Lancet 2013;381:2044-53.

31 Ouyang HY. Five top safety issues of Chinese in 2011. Insight China 2011;7:50-4.

32 Song Y, Li X, Zhang L. Food safety issues in China. Iran J Public Health 2014;43:1299-300.

33 Iliff AR, Jha AK. Public-Private Partnerships in Global Health Driving Health Improvements without Compromising Values. $N$ Engl J Med 2019;380:1097-9.

34 Ministry of Education, People Republic of China. Statistical report on international students in China for 2018. Available: http://en. moe.gov.cn/documents/reports/201904/t20190418_378692.html [Accessed 15 Feb 2019].

35 Li Q, Gloyd S, Xu D, et al. Global health education in Chinese universities and potential for collaboration with schools of nursing: a qualitative study. Int J Nurs Sci 2017;4:12-18. 